\title{
An Interview with Angus Wilson
}

\author{
Frederick P. W. McDowell
}

F.M.: You have presented your views on Dickens at considerable length in The World of Charles Dickens. Obviously, you couldn't say very much there about Dickens' influence on you. Personally, I feel that the organization of a Dickens novel may have had some bearing on the structure of your novels. Like Dickens you tend to have one or two characters presented in some detail (especially with respect to their moral choices), surrounded by a group of characters presented from the outside. Dickens illustrates this principle in surrounding Pip, Arthur Clennam, Esther Summerson, and David Copperfield by externally conceived characters. Do you admit to such a principle of organization in your fiction?

A.W.: Yes. I have read Dickens since I was very young, and I suppose I have read him more often than any other author; and he inevitably goes very deep into my work. Apart from the humor of Dickens which lies very close to a good deal of my humor, what is vital to his approach and to mine is that he sees his central figures always in relation to, first of all, a group and then in relation to the whole of society. Frequently with him the direction in his novels is, rather, outward from society and inwards toward the group and the central figure but always in connection with a great number of other people; he sees the central figures internally and the others are presented externally. On the whole, this has been my method. It has been the only way, I think, in which I can present my sense of man's total isolation, his working out of his problems within himself but also in terms of the other human beings whom he comes across. I would say, however, that I am an agnostic and Dickens is a Christian. Therefore our view of man's potentiality is obviously different; but insofar as we are dealing with this world, I think Dickens was very concerned, whatever his beliefs in the future life, to see what man could do with himself. He frequently wrote about what had gone wrong with a man's life. Little Dorrit is a very good example of this preoccupation. How can an individual face up to failure, to seeming guilt, to a heavy burden of responsibility, how can he free himself? My books are very much about the freedom that is available to man and what he does with it. I think that both Dickens and I have a rather limited view of what that freedom is, of how much freedom is left to a man. Nevertheless, I start from the same kind of temperament as Dickens', that is to say, I am a person who is almost immediately drawn to people. I like very much being with people, I like individual people, I am excited by them; but I am also liable to fall into a deep sort of boredom. There is in my love/hate for people (save a very

This interview took place during the fall of 1971 while Angus Wilson was a lecturer in the Writers Workshop and the School of Letters at The University of Iowa. 
few with whom I have made secure contact) a manic-depressive kind of love/hate that is liable, uncontrolled by reason and social ethic, to pivot violently. I think it would be much truer to say that it pivots beween a strong vitalism and a sense of emptiness and resignation. And this dichotomy, I believe, is also true of Dickens' work.

F.M.: In an interview a few years ago you mentioned the great influence on you of Richardson's Clarissa. You have implied more recently in conversation that Stendhal's La Chartreuse de Parme is such another seminal book for you.

A.W.: They are two novels which I admire very greatly indeed. I read Clarissa first when I was about eighteen, and I have read it a number of times since then. It has influenced me, I think, in two ways. One, I think there is no novel in which that sort of building up of realistic detail into what is finally a grotesque or fantastic form occurs so firmly-something which you find in Dickens when he speaks of Bleak House being the romantic side of everyday things. Richardson had this capacity to create by lots of realistic details what is finally the appearance of realism but which is, in fact, something extraordinarily fantastic. The power to imprison both his characters and his readers is something that $I$ have always aimed to do, because my books are about people imprisoned and how they break out of prison. My characters have to break out with what is left to them in this life, whereas Clarissa triumphantly and wonderfully, in what I think is the greatest Christian novel ever written, breaks out and goes to her heavenly bridegroom. But I would also say that Clarissa has influenced me in another way. I have always felt that I am concerned deeply in my books with the hopeless, the lost, those who don't matter. All my books are about the necessity of taking these people into account. And it seems to me that even these days women belong to this group of the disregarded. They are still the victims of society, not of course to the same extent that they were; and, indeed, many of the great feminists are very good examples of what happens as a result of victimization. I think that Clarissa has influenced me enormously as the supreme representation of this understanding of women as victims. I am always interested that women readers of my books fall into two categories, those who state that I have understood women very well (because I do see this tragic denial of their full rights) and those who say that I am very horrible to women (because, in portraying the denial of their rights, I do show them in the shabby lights in which they can appear when they try to evade or accept their imprisonment). And I think that some of the ambiguity of Clarissa, of women seen as both victors and victims, arises in this way. But I would really say that Clarissa is a superb book to me because, finally, with the certain defects that Clarissa has, she is a great woman who breaks out of her bonds without artifices which are unworthy of her-very, very differently, for example, to Pamela. La Chartreuse de Parme is also a novel that I love and reread often. I wish I could say that it had influenced me in the same degree in my writing. I fear that I have never been able to attain in my novels that sense of the totality of passion found in it: I mean by that totality both love and sexual passion, romantic love when people are deeply, 
deeply attracted to one another. No one, I think, has understood so well as Stendhal the supremacy of passion, the way in which such abandonment to emotion can create a sort of happiness that transcends absolutely everything. Further, he understood how this transcendent passion can quite suddenly, as at the end of La Chartreuse de Parme, collapse into a strange kind of dust. This sense of collapsed passion perhaps I have been able to convey. Also I would say that just as Clarissa represents woman triumphant and victorious but, of course, a martyr, so Sanseverina represents woman using her femininity: not using it in a manipulative way but enjoying it and her sensuality to the full-tragic also, but the other side of triumphant woman. I wish that I had created a Sanseverina; certainly she is one of the great characters of all fiction. The only heroine in the English novel, I think, that approaches Sanseverina is Clara Middleton in The Egoist. She combines intelligence, youth, vitality in a way which Jane Austen achieved in Catherine Morland but never captured again. Clara seems to me to live, untrammeled by her author, as, say, Dorothea Brooke or Gwendolen Harleth or Isabel Archer never do. In her spiritual authority and largeness of nature she is the heiress of Clarissa.

F.M.: You once said that Dostoevsky is the greatest of the European novelists. This statement would imply that he has influenced your view of human beings and their psychology, possibly also the themes developed in your novels and the techniques used in them.

A.W.: Before I begin to talk this time, I should say that my pleasure in discussing great names like Dickens, Richardson, Stendhal, and Dostoevsky by no means implies that my work ought to be compared to theirs. But I do think that a writer can legitimately define his own views, the contours of his work, and his technical problems by considering them in relation to the novels of those by whom he has been most deeply moved and impressed. Perhaps a serious writer can think of his own art and the issues it raises in no other way. And it would hardly avail, out of deference to greatness, to discuss, instead, writers of lesser importance, those who have failed to capture one's imagination. So please regard these great writers as representing standards of excellence hardly to be attained by anyone now writing and their works as points of reference for discussion of the art of literature. As for Dostoevsky's psychology, I am interested in it very much and I think that it is very remarkable. I don't know that I have ever successfully captured it: that is to say, this extraordinary capacity for the emotions to change suddenly in a person, this apparent lack of relation between their actions and their words, this all but total rejection of logical motivation, and so on. I am impressed by his insight into human unpredictability, but I am not quite so impressed by it as I used to be. I do think sometimes that it's a bit of a trick. I think that sometimes, as in D. H. Lawrence, what Dostoevsky succeeds in making us think is a natural and extraordinary impulse is, in fact, a very carefully worked artifact. But still it is true that I wish my work were more influenced by this sense of the unpredictable and were less deterministic. It has been my fear that the influence of Zola, for example, whom 
I admire greatly in other ways, has led to too great a determinism of my characters. But where Dostoevsky has influenced me enormously is in his concept of the relationship existing between society and chaos. He thought, as indeed I do, that society and civilization rest on a very thin ice. This view led him to be very reactionary in politics. It hasn't led me to be so, but I do think that there are (and we have seen them in recent times very greatly) malevolent forces at work, unhappy people who, through being twisted, are really concerned more to break up civilization than to do anything particular with it. And this kind of growing hysteria that you get in his novels-markedly in The Idiot and in The Possessed but in all the novels where they begin, you know, so frequently in the province of $\mathrm{X}$, with reports that there have been recently a number of senseless crimes and so onthis sense that there is some kind of chaos at work somewhere, which can usually be traced to one or two characters in the book (Pyotr Verhovensky notably in The Possessed), and which culminates usually in some public gathering in which all chaos breaks loose and the forces of good, the forces of humanistic duty, and so on are for the moment routed-this has been a pattern enormously present in my books. It conveys, often, the sense of the individual alone in a crowd of people (and of hostile forces) if you like; and it's particularly, I suppose, to be seen at Vardon Hall in Hemlock and After. I could think of many, many examples of this induced chaos in my books, and malevolent figures as in Dostoevsky are to be found there: the architect, Hubert Rose, in Hemlock and After, Gilbert Stokesay in AngloSaxon Attitudes who perpetrates the whole of the Melpham fraud simply as a kind of joke against life. These kinds of malevolent figures and the upsurge of what they do, culminating in some great party or public meeting, the ensuing chaos, and then the gradual bringing together of what little remains of order, represents what Dostoevsky has chiefly given to me.

F.M.: In a talk which I recently heard you give, you said that Samuel Beckett is the greatest writer of our time and you also mentioned that, among contemporary novelists, you admire Nabokov, Borges, and Montherlant. I wonder if you would care to comment briefly on what each of these writers has meant to you.

A.W.: Yes, I think that there is a distinction to be made between Beckett and the others. Beckett is usually counted as anti-humanist, but I don't see him in that light. I've written some reviews suggesting that he is, in fact, a considerable humanist but a humanist of man at his stage of final disintegration. He still thinks man worthwhile enough to make him the center of such novels as Malone Dies and so on, where you get just what is left when man is finally nothing much more than a body. I think he takes on from the humanism of Joyce, in the wonderful representation of Leopold Bloom who is one of the great figures in fiction to me. And I have felt that some of my tendency to try to bolster up the humanism of my characters in my novels with what are, after all, the accidentals of culture, of natural perception, of talent and so on has been corrected by this viewing of man in a reduced way as Beckett does. Beckett's rigor has been a corrective to what I feel to be 
the rather false humanism which I inherited from E. M. Forster's novels, a humanism derived from one segment of middle-class civilization and not from humanity in general. I have tried in my later novels, at any rate, to work somewhat from Beckett's position. Even in my early stories I always, as I hoped, balanced everything as much against my characters as for them, so that there would be no patronage, so that when they came through they'd come through on their own account and everything that could be said against them had been said. But I think that I wasn't always scrupulous enough with them; and I have increasingly tried-and Beckett has influenced me greatly here-to let them stand alone as perhaps Sylvia Calvert (Late Call) does, divested of all that contemporary society has given them but still able to win through in some degree. Now the other three-Borges, Nabokov, and Montherlant-are, I think, anti-humanists. I admire their work technically and, indeed, the power of their minds and their wit; but I don't admire their particular kind of aristocratic disdain of man. However, they have been again great correctives to any sentimentality that I have (and I am sure that I have got it) in my treatment of human beings. Particularly, I have taken from them the elements of parody, the use of parody of civilization, of culture as it is handed down to us in literature. Parody becomes a means of alienating the reader, of ensuring that he does not become over fond of the characters, of preventing him from regarding the book as a "good read" and from being unable to see where he's going because he's too absorbed in it. I think that Tristram Shandy is a great beginner of this willed alienation of the reader, and it is a technique that we can't afford to do without now. I think we must be prepared to alienate our readers at times so that they shall not go through our books as by rote, feeling comfortable and happy and feeling that they are reading warm, moving books. And I have endeavored to keep my readers at a distance from my books with parody, notably with the plays in No Laughing Matter; but also I began it in Late Call and this attempt I think was not noticed. I wanted to present Sylvia Calvert, as a typical Anglo-Saxon, low-brow, middle-class woman whose contacts are with pop culture. And I wanted to suggest that involvement even of this sort can be a very meaningful thing, that somebody can make out of pop culture-out of telly and magazines and ordinary romantic biographies-something that will teach her about life if she has the toughness and fibre to use them in that way, whereas popular continental culture (I mean in Germany or France) would hardly allow her to have done so. Frequently, ordinary people in these countries are more educated and therefore more culturally snobbish; and the middle classes in these countries very often are satisfied with an obeisance to higher culture represented in my mind by the idea of morceaux choisis, the selected pages from the classics. I put Sylvia Calvert directly in confrontation with a Polish woman who has been through all the terrible things that have happened in Russia, in Germany and so on, in China, in the years of our lifetime; whereas Sylvia Calvert has done nothing but run a hotel in England. Yet she emerges as having been touched by life, as having been altered by it, whereas this woman, 
poor thing, has had the most terrible time but she's been really untouched by life. And the representation of this insensitivity is her use of fabricated morceaux choisis from all the great writers, Tolstoy, Grillparzer, Strindberg, Pushkin, Byron, and so on; and all the quotations that I cite from those writers that she uses were made up by me. But none of the critics noticed this at all. These fabricated quotations were a way of suggesting that this particular kind of high culture as it is used in continental countries is often a soporific rather than a means of making people think, a way, too, of suggesting this woman's arid nature in contrast to Sylvia's life-enhancing qualities.

F.M.: I was interested to hear you say recently that you regard Hemlock and After as in some ways your best work. I admit the power and strangeness of the book, and I wonder what qualities or aspects of it you now most admire.

A.W.: I think that I hold Hemlock and After in esteem because I was totally untutored when I wrote it. I had written my short stories but they were quite different. They were little bits of my life which I had transformed into stories. Then for the first time I had to organize my experience into a framework. My models were primarily Victorian, I suppose, but my sentiments were modern and sophisticated. This contrast is what I like about the book, although it makes it somewhat ludicrous. I remember a reviewer, Walter Allen I think it was, saying that Hemlock was a very strange book because it combined pages as it seemed from the Victorian schoolboy classic, Eric, or Little by Little [by Dean Farrer] (I think he was referring to the boy whom Bernard loves called Eric who is really treated like a Victorian waif-hero) and from Petronius Arbiter's Satyricon. I think what I like about my book is that it has this strange sort of primitivism and this same kind of sophistication, and that I was too naive to be able quite to marry them. And so it makes it a very odd book, a book in which all sorts of different modes are present in the same pages-Mrs. Curry who is totally Gothic, Bernard Sands who could come out of Gide, Ella Sands whose extreme and sometimes unexplicable neuroticism and withdrawal might suggest Dostoevsky, and so on. This mixture of elements and modes makes it a failure as a novel. Anyway, I wrote it in four weeks so that the work is too truncated; but it has an originality and a directness, a freshness, which I think I have never achieved again. The localized violence in that book, which is different in kind from the overt public violence present in, say, the Fascist scenes in No Laughing Matter or in the war scenes in The Old Men at the Zoo, has an impact at the Vardon Hall scene in particular, I think, which perhaps I never achieved afterwards. Hemlock has all the themes that I'm going to use later, but it's an unskilled book. It's a book written before I had started to think about technique in writing; it's a book to end all writers' schools, and I rather love it for that reason.

F.M.: I have been interested in your note to Hemlock and After to the effect that Ella and Bernard are "in a sort of way fulfilled and partly life-loving" [even at the beginning of the novel, I would assume], but that they have given 
Elizabeth and James "emptiness, power longings and death wish." Would you care to comment?

A.W.: Yes, I would. This whole question connects very closely with my play, The Mulberry Bush, the history of the Padleys who also fail with their children and their grandchildren. I think this failure sums up my case against liberal humanism. I don't want to go on making that case, and I have given up in my books doing so: the case has been made. It seems to me that what is left of liberal humanism is one of the most hopeful forces we have in the world. But no doubt it has lost out in great degree because of its hypocrisies and because of its failure to come to terms with itself. One of the things it did, I think, was to suppress all recognition of some very essential aspects of human nature. People like Bernard and Ella well represented sweetness and light; but they were often arrogant and masterful, insisting that sweetness and light as they had conceived them should be taught. They had this Arnoldian quality of wanting to make sure that "the barbarians" and "the philistines" should adopt their views. I think that their children had the same feeling: that their parents did love life, were fulfilled, did have the right ideals, but wanted no one else to voice values around them other than their own. The narrowness is emphasized by Ella who calls anything foul that doesn't quite fit in with her liberal scheme of values and dismisses it as that. I think that the Sands children inevitably must have wondered about such things as emptiness, such things as power, such things as not being on the side of life but being on the side of death, such things as the sordid and evil aspects of experience, all the things which are unmentionable, for unmentionable things are always exciting to children. These liberal humanists thought that they were sweeping away outmoded values or were opening up the cupboard doors of the Victorian world and letting in light and sweetness, but they were also excluding from discussion many integral facets of human nature. They made, for somebody like James Sands, the idea of power much more attractive than it really is because it was in the Sands household such an unmentionable thing and because Bernard and Ella were also using power though they never mentioned that they were doing so. Equally for Elizabeth, there is this sort of attraction for her, I think, of a world that is full of trivial, worldly values because trivial, worldly values just were never mentioned to her. And Bernard's and Ella's lives, just like many other people's, were a bit trivial and empty and worldly. So it's the banishment that was the great error. The refusal to allow the discussion of the matters which they had banished came back at them retributively, a refusal that has corroded a great deal, I think, of the power of liberal humanism. My hope is that liberal humanism-or what remains of it-is now on a firmer base and can, in fact, be more effective in the world even if its prestige is no longer so great as it once was.

F.M.: One quotation from Anglo-Saxon Attitudes, as it bears on Gerald Middleton's problem, seems particularly significant to me. With respect to the Melpham fraud and his need to expose it, Gerald says that "it's not my conscience, it's the good faith of a humane study in a world rapidly losing its 
humanity that matters." I regard this sentence as basic not only to Gerald Middleton's values but to your own.

A.W.: Yes, you're quite right; this is my view. I think that concern with one's own conscience is necessary because it allows one to formulate the values for which he stands; but David Parker in The Middle Age of Mrs. Eliot, despite all his good qualities, stands somewhat condemned because he's concerned so much with his own conscience that he's really not too able to respond to the wider values which it often suggests to him. I think this concern with wider values is one of the splendid things about Gerald: he's the hero of my books who's been the most popular with readers. He is popular perhaps for the reason that people do feel that he's a man of great courage and a man who is rather selfless, though he has been very selfish. The only thing I would criticize in this query of yours is that I would never put a sentence of that kind into any character's mouth now. It is too explicit a statement of my aims in the novel. The criticism I would make of Anglo-Saxon Attitudes is perhaps that at that stage, for technical reasons possibly, I didn't realize how essential it was to let the theme of the novel speak for itself. I do not mean that you cannot, as George Eliot did, make moral statements in the novel. No, not at all; you can use any form or technique that you like. But I think that all readers are lazy. The reader who is given the statement explicitly like that will read it, be satisfied that he knows what the book's about, and in all likelihood not feel it. It's only by making the idea work through the novel, which I think it does also in Anglo-Saxon Attitudes (at least, I hope so), it's only through that part of a book which a reader feels, that it exerts its spell. It's, after all, his feelings you want to capture rather than his immediate acquiescence; and such a statement made directly may lead him to think he needn't bother to feel or to explore the book conscientiously because he now knows what it's all about.

F.M.: Would you agree that a large cast of characters as in Anglo-Saxon Attitudes is necessary in order for you to convey implicitly-by the means of ironic contrasts-the various kinds and degrees of self-deception and the limited kinds of illumination present at times in your various characters? And perhaps when you are discussing the characters, you would like to say something about the academics who figure so largely in this novel.

A.W.: It is a novel about self-deception; it is a novel about the English class structure as well. Mind you, I don't think that social differences are absent in other countries; other countries have their own hierarchies-in your country, there is probably a hierarchy of status or meritocracy or whatever it is. But the structuralization of society, the stratification of society, is something that I've always fought against. I have tried in this book to show the degree to which people are limited and are able to deceive themselves, because they belong to a particular group which never associates with other groups; then they are brought into conflict with those other groups, often with explosive results. I used homosexuality in this novel specifically for that reason, because in the modern world (or perhaps not so much now but twenty years ago) it was one of the half-secret societies which very often transcended the 
class structure, so that people were forcibly brought into touch with other people from a quite different social sphere to their own. All criminality has this effect of erasing social barriers, I suppose, or anything which is treated as criminality does so. But one of the ways in which I used my large cast was to show that stratification happens and that people deceive themselves when they think that it does not happen. People are able to live with only half a heart, to live without real compassion, because they are able to utter words that are only forms. They have what's called a private language. We run right forward here to No Laughing Matter, my last novel, where humor is a protective device and where the language of the theatre isolates the Matthews children from others even though it gives them strength to resist parental neglect and cruelty. The language of a particular in-group is a protection against that in-group facing the realities of what they are doing or communicating with those from other groups and classes; and the academic world is peculiarly prone to this evasiveness. Within itself it has all the hierarchies that exist in the world and total structure of society, I think. You notice that in Anglo-Saxon Attitudes the foreign professor visiting is treated in a special way and also that people from the various structures-the professors, the associate professors and so on-all have their own little roles and modes of communication. This self-deceptive language which is common to the people in any stratification is especially marked in the academic world; and academics, because they occupy a pinnacle in public esteem, are peculiarly liable to use it in a way which is self-diminishing in their combination of contempt for others and glorification of themselves. The universities and education in a humanist world have, in some degree, taken the place of the church and religion. In the church in the nineteenth-century novel the clergy were those who were most liable to hypocrisy, as indeed of course they were liable to the greatest heroism. When one thinks of people like Mr. Stiggins, one should also think of the Rector of Hogglestock. There were great churchmen just as there were failed churchmen, and this observation is true also of academics. I hope that Gerald is in my book a successful and good and great academic and indeed that Rose Lorimer, though tragic, is another kind of great academic. But there are the Professor Cluns in a university; and they are partly the result of the scholar's typical remoteness from life. The Professor Cluns must go on pretending that the academic values, the humanistic values, or the scientific values to which they have been devoted are still the center of their lives, even if they no longer really care about learning. Professors run all the dangers that churchmen ran in the nineteenth century, and above all, they are all too often treated as a kind of god. This is particularly the situation in continental universities. Nowadays, of course, their arrogance and exclusiveness have come back at them with student revolt, with increased public scrutiny of their work, and so on; but for a very long time, and still in my Anglo-Saxon Attitudes, the academics are handing it out to everyone. This disdain and remoteness are even more true, of course, of schoolmasters and particularly of headmasters. Harold in Late Call is such a tragic and a self-deceptive figure because the schoolmaster and the headmaster, even 
more than other academics, is the person who is able, simply by his position, to demand acquiescence in all that he says and to go on pretending that the values that he once held are still relevant when in effect they may have ceased to be so. Nobody can say no to him; he will be a tyrant in his own family; he is liable to more moral obliquity than any individual from any other group of people I know. All this came on me first, I suppose, when I worked at the British Museum. I was employed there with a number of other people at a very poor salary to redo the catalogue in the 1930's. When one time I mentioned to the Superintendent of the reading room, a very amiable and a good man, that we weren't able to afford even proper lunches, he was horrified because a consideration such as this, of money, didn't enter into the little closed world of academic and scholarly values that he liked people to discuss. He looked up at the very high dome of the reading room and said, "Well, yes, I suppose so, but after all you do have the inestimable advantage of working under this great dome." This observation made me feel that hypocrisy could be found in greater degree in the academic world, simply because of the pinnacle on which the public had placed it, than perhaps anywhere else. But I dare say if I knew the medical profession I would find much the same thing.

F.M.: In Anglo-Saxon Attitudes you have written, it seems to me, with much insight about a complex moral problem. In a note to the book you have indicated that, from the standpoint of Gerald Middleton's career as historian, the proclamation of the truth will make for order, but that the abrupt introduction of the truth in the family circle will, instead, produce chaos with much attendant suffering. Are you implying that it is sometimes preferable to disguise the truth, or is domestic dislocation and suffering to be preferred to evasion of reality, no matter what the cost? Perhaps you might also want to say something at this point about your characterization of Ingeborg.

A.W.: Yes, I suppose that here I am thinking of Ibsen's The Wild Duck. I wrote an early short story called "Fresh-Air Fiend" which makes this point. I do believe that there is very often a self-indulgence in taking upon one's self to tell people the truth about their situation. In matters of public concern, in matters of academic or scientific truth, I think that there is no question about one's obligation although such a revelation of truth is almost bound to cause some suffering to colleagues. A very sad character in Anglo-Saxon Attitudes, the most tragic character in a way, Rose Lorimer, is the one who suffers most when facts as she has known them are seen to be false. She cares more in a way, I think, about history than any of the other people; she has a vein of poetry; she tries to unite these two qualities of mind, but she goes from this effort to a distortion which is, in fact, a falsification of the science which she professes. She is the victim of the clearing-up of this matter about Melpham, and she must be so. Decisions in life have unforeseen consequences; all these problems that one puts forward in one's novels can't be solved without loss. And the loss which must be on the conscience of Gerald Middleton and his other colleagues for the rest of their lives, so long as she doesn't recover her sanity, is the terrible blow that they have inflicted on a good 
woman, Rose Lorimer, in the interests of serving abstract truth. But in the cause of a discipline like history, I am afraid this exposure must be made. But when it comes to private matters I don't believe that the plain truth, suddenly revealed, is always constructive. Private matters are much too complex, and interrelationships have gone on too long and are too deeply ingrown for somebody to be able to come in and unlock the puzzle just like that. It is an arrogant thing to do; and, on the whole, I don't think that such action works. It's to suppose that you are God in relation to people. I think that Gerald tries to strip away pretenses in his family and he fails. That he fails seems to me to be quite to be expected; that he is able to face his loneliness when he finds that he fails is admirable. In part, this failure is due to the nature of Ingeborg. It might be thought that Ingeborg is a weak antagonist to Gerald in this matter. She is an unteachable woman, she is almost stunted, she is child-like in the worst sense of the word perhaps: children can be both delightful and not grown-up, and Ingeborg, I am afraid, is more immature than charming. But Gerald is in great degree responsible for Ingeborg's condition. He marries her when he is really in love with Dollie Stokesay. Nobody surely has a right to act so falsely, as Bernard Sands also proves by his suffering when he marries Ella even though his tastes were really homosexual, I suppose. But Gerald is really more culpable than Bernard because he chooses someone who attracts him for the moment, brings her as a young foreign girl to England to a totally alien environment, is totally occupied with his historical studies, and is not very concerned with how she will get on in an academic society where she has nothing in common with other people. In a fit of hysteria she does physical damage to her daughter as a child which is irreparable. This crisis fixes her forever, I think, as a kind of sunny, optimistic child, incapable of honestly facing the consequences of her acts. All her life she wants just to think only the good things, to think comfortably and evasively. It's notable-and I meant it to be so-that the only person who really hits at her hard and is brutal to her is another person who is childlike, Larrie. He is himself a kind of criminal child, and he hits her as one child might hit another. But when Gerald finally exposes the family truth about Ingeborg, the children all rally round her, the sons and daughters. I think it quite natural that they should do so because they see that, for all her enormities, for all her absurdities, and for all her sweet evasions, she is a child. The responsibility for her having been made into a perpetual child is really Gerald's. She is a Dora as I see David Copperfield made Dora; and as such, I find Dora a moving figure. If I were suddenly to find myself in the world of David Copperfield, I should rally round Dora every day rather than round David.

F.M.: Let's go on now to The Middle Age of Mrs. Eliot. I think that the fascination of that book resides in its presentation of a strong character whose strength is never tried until she loses her husband. Then she makes a number of egregious and often embarrassing mistakes, attempting to impose her sometimes irrelevant standards on the lives of others; and she remains unable, for a long time, to accept people for what they are. Yet she does 
finally achieve strength. In some ways, it might be said that she has to lose her soul in order to find it. Would you care to comment on these remarks?

A.W.: Yes, I think that the story of Meg Eliot (it is my most existentialist novel if one is going to use rather pompous words) is about a person who does really change her whole existence. She is a rich woman; as a rich woman and a petted woman, she behaves, on the whole, rather well. She is a woman who tries to live her life sensibly, to do good and not act in a patronizing way; she adores her husband; she's full of interest in literature, in the arts, in life generally; she's drawn to people and she's compassionate towards them. But, of course, her life is founded on a hollow basis, as she is to discover when she learns that her husband dies a bankrupt as a result of his compulsive gambling. His gambling is a sign of how unreal to him the marriage was, how she had imposed her standards upon him in all his other activities, and how without realizing what she was doing she had denied him his full rights as a person. The story to me is a story of the nemesis of power. In all my books I am always against power and the insidious nature of the corruption it brings. Meg Eliot uses power well, but she uses it. She finds that the power she had wielded is totally hollow, it comes back and hits at her, so that she has to go right back to "the nursery" through her subsequent attempts to come to terms with other friends of hers who have come on evil days. Most of those have sought neurotic refuges far worse than anything she's to find her place in. Eventually, with her brother she goes right back to where he runs a nursery garden; and it's not for nothing that this move is back to "the nursery," to the very origins of her life. She has to be born again, and she is born again. At the end she goes off and resumes an active life in the contemporary world. Who is to say whether she will now make more of a success of her life? I don't promise that she will, but I can only say that what she will do will be based upon a knowledge of the hollowness of power, of the hollowness of the egoistic will and its dangers for her, and of the need for action to be in some degree selfless. Whether she will succeed in her new life is questionable; but that she will be a less-precarious and a more certain woman-truly certain-that, I think, we can promise. And she is really letting us see that being a rich person is one thing and being a poorer person is another. Perhaps to be a poorer person is to have a firmer foundation in life than to be a rich one. Here is a place where I challenge the over-certainty of the Forsterian ethic where both the poor like Leonard Bast and the rich like the Wilcoxes are cut off from a meaningful inner life. I think we cannot be so prescriptive in these matters and that they are subtler than Forster would have us think.

F.M.: I agree with your comments in The Wild Garden that David is not the moral center of The Middle Age of Mrs. Eliot as some critics have thought, because he is, ultimately, too passive and bleak in outlook. Yet I think he speaks for you, in this book and others, in this formulation: "he lay meditating on the mystery of man's supreme value and of his utter insignificance which demanded in turn the mysterious power to love and to remain apart." To what extent do you support this statement, then, and to what extent do 
you regard the cultivation of the contemplative life as a necessity in the modern age?

A.W.: Yes, indeed, I do. I think the difficulty is that, as in every other activity in life and in my novels, the truth lies in a contradiction. The most you can hope to achieve is some kind of balance, and David fails in achieving a balance. It seems to me like writing: I describe writing sometimes-fictionwriting at any rate-as an extraordinary activity, a contradictory activtiy because you have to allow the whole inspiration to well up in you-that is to say, you have to be passive-and then you have to sit down and actively write. So you've got to be both passive and active at the same time. And the trouble with David is that he ignores the active role. Contemplation is, however, a great, great necessity in the world, and he realizes it. Meg in the early part of her life has failed to contemplate at all. David has learned the need for contemplation, but unfortunately he only contemplates. The key words which condemn him, I suppose, are: "he lay meditating." The trouble is that he lies meditating throughout the book and he would happily remain so, recreating his childhood again with Meg if she didn't walk out on him; and he is incapable, really, of action. David's view of man as insignificant and of supreme value is, of course, paradoxical. I share this view. And I note that David calls for an active love as well as remaining apart. Yet he is incapable of such activity.

F.M.: Let us go on to a book that I feel has had much less than its due, The Old Men at the Zoo. In an inscribed copy at The University of Iowa Library you assert that it is your best book. I also admire it very greatly: I like, for one thing, the kind of fable that it is. More fully than many fables, such as William Golding's Lord of the Flies or The Spire, the book is rooted, I think, in a discernible and believable contemporary reality. Also I think that the power of the book is largely to be sought in the metaphors which work so very well at both the actual level and the symbolic level. Would you comment?

A.W.: The Old Men at the Zoo is perhaps loved by me very much because it has never-or has only recently-been much admired by the public, whereas Anglo-Saxon Attitudes is perhaps my least favorite book because it's always been so well received (but that's a purely personal thing). I do admire it very greatly because in it I deal with one of these contradictory aspects of life, perhaps the most vital, I think, of all, the relationship of the individual to power in society and to his internal culture through his relations to the natural world. The book sets for the central figure, Simon Carter, a dilemma which seems to me to go deeper than practically any other in which my characters are placed. He has the capacity to be a naturalist, he has an intuitive relationship to the animal kingdom, and he's also got a remarkable power of administration, of running the lives, the organization of human beings. This is a rare combination, perhaps an unfortunate one, and certainly a very unfortunate one for him because he finds it impossible to combine his divergent talents. In the end he sacrifices all, perhaps, by sacrificing his natural and intuitive bent. But somewhere or other, one must develop one's natural and intuitive side and to do this in conjunction with one's social and organizational 
side. I believe this double development is an absolute necessity for men living in urban communities, perhaps for men wherever they may live in our modern society. This problem seems to me to be well worked out in the novel, as you say, on the allegorical basis. I think the novel would have been more successful-and Evelyn Waugh spotted this; he was a very wise man-had I laid it in a triumphant German invasion of England in 1940. I had originally intended to do so, but I was told that I would be laid open to libel law, in giving this or that attribute to the various keepers of the departments at the zoo, by the people who had held those offices at that time. So I set the novel in the future; and to some extent this has caused people to identify my book with scientific prediction, an activity that I was not very interested in in that novel. But I was concerned with organization and also with the concept of administration and organization as being fundamental for the life of man in society. You know, the organization man sees the world in his own terms. I think it was perhaps a certain antipathy to, or at any rate a distrust of, the universe of Snow's novels that led me on to this book. When I read Lewis Eliot and his very brilliant and true account of the intrigues that go on among people in high office or in the bureaucracy or whatever it was, I used to think, "But what would have happened if these men had been in Vienna in 1938 when the Anschlüss happened and the Nazi troops walked in overnight?" What would then have become of all the machinations and the intrigues that were going on in the novels of Snow? They would have been put an end to, just like that. This is why, in a sense, I wanted to develop all those intrigues about how the zoo was to be run and to be controlled; and then quite suddenly to change this whole situation. When civil and international war breaks out, an administrative intrigue at the zoo is all nonsense. So this was one of my leading ideas, the vanity of human wishes, if you like. But more important was my use of animals as a metaphor for human beings and my use of the various approaches to the treatment and organization of animals as metaphors for the different means used by those in power to control men in society. Particularly, I was struck by the impossibility of a man of good will and conscience and real intuitive understanding being able to administer efficiently if he hadn't fed his intuitive side. Simon is always about to do so in the book by going to view the badgers and studying their life. He's never able to nourish himself with these roots that lie deep in the creature world, in the natural world; and so, to some extent, his judgment and his will in relation to human organization gets weakened, and he gives way to all sorts of sentimentalities or occasional cruelties in his administration which would not, I think, have developed had he fed himself upon the intuitive roots that were so fresh and so real in him.

F.M.: In the case of Simon Carter I feel that his strengths outweigh his weaknesses, although, as you have indicated, his real weakness is his failure to feed the intuitive side of himself. I wonder if the fact that he is a rather strong individual morally might have had some bearing upon your use of the first-person in this novel, since this is the only novel in which you do use a first-person narrator. 
A.W.: It's very interesting that you should raise this question. I have in my novels a tendency (and my natural inclination in writing lies this way) to disguise myself. I think that I appear (now I'm undisguising myself but what I am to say will be obvious from the things I have said before) in Meg Eliot, I appear in Margaret Matthews and in Marcus Matthews and in Quentin Matthews; but I do not appear in Simon Carter. Simon Carter is taken from someone whom I admire very greatly, a person who had an artistic side and considerable administrative power but who, because of the intricacies and the demands of administration in the modern world, was forced to relinquish his artistic side to the detriment, finally, of his human relationships and his capacity to administer. This dilemma of his (because I admire him greatly and I think he succeeded more than I would have been able to do) did interest me. I thought that because it was not myself, because it was somebody else (and I can say this even though these remarks appear in print because the person knows that it is so), I could speak as an "I," since I knew that I was dealing with somebody who was not me. That does not mean to say that I am not without Simon's particular dilemma as is clear in my lectures, The Wild Garden. But I've never been placed in that particular administrative position, and I've never had to relinquish entirely the intuitive and artistic side of myself. I've not been faced with this dilemma in the way this person was whom I admire so greatly. Simon was drawn directly from somebody else than myself, and I felt able to use the first person. But Simon's character may finally be a self-disguise: I don't know.

F.M.: In your essay, "Evil in the English Novel," you recognize the necessity to recover the vision of evil as it is pitted against the good, to supplement the dominant dichotomy in the British novel after Richardson, that between right and wrong. Now this vision implies that evil is something given, gratuitous, ultimately inexplicable, but a force, too, with which the sensitive individual must come to terms. Much of the success, to my mind, of The Old Men at the Zoo consists in the arresting way in which this sense of gratuitous evil pervades the novel, from the time of young Filson's being savaged by the giraffe to the introduction by Blanchard-White (a kind of demon originating almost from nowhere) of the gladiatorial combats at the London Zoo, before the final liberation of England from Uni-European domination. Would you please comment?

A.W.: Yes, I think this statement would cover the whole of my novels, really. From the beginning of the first novel, Hemlock and After with Bernard Sands, there is a constant sense of evil and an embodiment of this evil in characters like Mrs. Curry and Hubert Rose, right away through the others to Sylvia Calvert (Late Call) being haunted by a sense of evil. In The Old Men at the Zoo, evil comes very close to being identified as a wider force than anything that can be put into one character or even into a few characters. All this may account for the power of the last part of that novel: I am glad you feel that. However, it seems to me that because again of this transference of the situation in The Old Men at the Zoo from possible Nazi conquest in the 1940 's to an imaginary situation in the future, it gets a little off beam. I am 
not happy, since I am a humanist and not a religious person, at the idea of a personal devil. I don't believe in a personal devil; therefore, there is something a bit worrying in my attempt to embody such a devil in characters like Gilbert Stokesay or Mrs. Curry. To do so is false to what I really believe; it's much more appropriate to Dickens with Fagin or so, because Dickens did have to some degree a belief in a personal devil. It's certainly very appropriate to Richardson with Lovelace because he also definitely had such a belief. But I don't; and so I felt worried by my projections of evil in my early books. In The Old Men at the Zoo I do make evil more pervasive: it's represented by Blanchard-White, but he's a rather shadowy figure. One just feels that he represents this wider evil, this capacity for cruelty that lies deeply in men; and cruelty is constantly the embodiment of evil in my books. But I feel that this whole problem of representing evil is really most successfully solved in my last novel, No Laughing Matter, where the novel embodies the evil I have actually known in my own time. Evil is implicit in Nazism and Communism (in their worst forms in the threat of concentration camps), in anti-Semitism, in other actual forces or processes. For this reason, I suppose, none of the characters, none of the six Matthews children though they are beset by many devils, are possessed by any kind of sense of there being a pervasive evil in and about themselves. They are aware of what evil is; it is something which they are actually contesting. Evil, as represented by the action of their parents in drowning the kittens in that novel (which is certainly a very nasty, brutish, childish act) is shown up for what it is: as a brutish, childish act. And it is mocked. The parents' attempt to turn it into something more metaphysical, greater, more devilish is mocked by my using the language of Lady Macbeth and Macbeth as the Countess and Billy Pop do the deed, so ludicrous is it to think of the Countess and Billy Pop as being Lady Macbeth and Macbeth. One sees that the pretension of any human person to being evil is a false pretension, is as ludicrous a claim in my scheme of things as a pretension to total sanctity. I feel happy that I have been able to evaporate this idea of a personal evil into something which is concretely set in the evil that I knew in my time, namely, anti-Semitism and the other social forces which we know of this sort. I think that the beginning of this tendency, as you rightly locate it, lies in the gladiatorial combats and so on of The Old Men at the Zoo which were very much ridiculed, I may say, by critics who took the view that we could never have this kind of savagery in England. But this attitude seems to me ludicrous; we have just been very lucky not to have had such oppressive social evil. But for the first time the diffused evil in society was there in my fiction, and it does haunt Simon in the book. But he sees it for what it is; he actually faces it; and he goes to a concentration camp. Part of Simon's difficulty has been his failure to see certain elementary forces for the powerful forces they are, Lord Godmanchester's honoring of power, Harriet Leacock's honoring of the animal world. These are forces that are too strong for the civilizing rationalism of Simon, and they also defeat Leacock. But Simon learns to see powers like these for what they are; and rather than suffer indignity from them he goes to a 
concentration camp. His accepting a job as administrator at the end of the novel does not imply a sacrifice of his values to opportunism. Whether as administrator he will be able to control in the future the forces that defeated him in the past is a question. But he is at least better equipped to do so than he once was. And there is a good chance he will be the best of the zoo administrators, particularly if he can find time to cultivate his intuitive side once again: yet the two sides of his nature may be tragically incompatible. Much though I like Late Call, Sylvia Calvert is still possessed and haunted by some curious kind of unembodied evil such as Gerald Middleton and Bernard Sands and Meg Eliot in her flight over the desert have known. True, I believe in this obsession by a sense of evil as a thing which happens to the human soul, but the idea that transcendent evil can be embodied in one particular person is really nonsense in the sort of agnostic, humanistic code that I have.

F.M.: The Old Men at the Zoo must be read in conjunction with your formulation of garden symbolism in The Wild Garden and of how that symbolism may also be applied to the animal kingdom. In regard to this formulation, am I right in interpreting "the garden in the wild" as being projected in Leacock's open reservation for the animals and "the wild garden" as having two manifestations: in the cage zoo (where animals are restricted according to good Victorian practice) and, more constructively, in the attractive cottage where Simon finds his beloved badgers at last, only to be forced, for prudential reasons, to eat them, and figuratively speaking, to become a kind of cannibal. Actually, in some sense he might also be illustrating the truth of Oscar Wilde's idea that "each man kills the thing he loves." Would you want to comment on these statements?

A.W.: Yes, I would say that you are quite right in saying that Leacock's open reservation for animals is "the garden in the wild." I would not accept the idea that the cage zoo is "the wild garden." "The wild garden" is, I think, the garden where Simon in his flight eventually finds himself and where he's forced to eat the badgers. Strangely enough, I found myself following a route out of London I knew, when Simon and Beard are escaping. This is a minor route which you can follow, to reach the present part of the world where I live, in Suffolk. When I came to write about the cottage garden, there's no doubt at all that it is my own garden. I had arrived at my own cottage. There are badgers in the wood near where I live but I have never seen them. I had come back to my own garden which I have tried to make into a wild garden. Other components of the novel like the cage zoo, Beard's treatment of the animals as purely scientific objects (an attitude which he combines curiously in an absolutely schizophrenic way with the Christian faith), and then again, Englander's idea that the zoo will be a good one if we put enough money into it-all these are metaphors-simple symbols, I suppose-for various ways of handling men in society. But Dr. Leacock's program goes further than this; it is a kind of blueprint for a desired social organization. I think he says, "limited liberty"; and this, of course, is what many people think of as being the best way of running society, to give man 
limited liberty, though his daughter Harriet suggests that liberty is either complete or not liberty at all. I think that this is "the garden in the wild," because you do try to re-create liberty in what is not a free place. "The wild garden," on the contrary, is a place where wild things are to be found in a natural garden, in a made garden. But this wild garden to which Simon eventually comes in his flight and which is, I see clearly, my own garden, is very close to me. The killing of the badgers is very important. I chose the badgers, specifically, because they are, save for the eating of some eggs, almost wholly harmless to any other creature. What is also important is that they are very large mammals for the size of the English terrain. As Dickens found small things very moving, I find very large things to be so. The idea of whales, the idea of all those vast creatures like elephants, perhaps being in danger of being eliminated because there is no place in the world for large creatures-all this is to me something quite moving in itself. That badgers should not only be large but harmless is peculiarly poignant. And I think it is not insignificant that in my next book, Late Call, I go on to give to my heroine, who is ultimately a very harmless woman, the attribute of being very fat also, the fact that she falls over and is ludicrous as being fat, and so on. This is to me a very endearing quality. Perhaps I find it appealing even in Ingeborg Middleton. The large are always touching to me, as I suppose the small were always touching to Dickens. And it is also poignant, I would say, that Simon has hardly any choice but to kill the creatures that would nourish his best, intuitive side if they had been given the chance.

F.M.: One thing I find extremely moving in The Old Men at the Zoo is its sensual base, the perfect trust which exists, until the final pages, between Simon and Martha as husband and wife. Would you wish to comment?

A.W.: Yes, in The Old Men at the Zoo despite all the horrors of the book, I did want to portray four or five different kinds of married happiness. If you can remember, the parents of Filson, the keeper who is killed, are united by a great love of each other when their son dies. For all his absurdities, for all even his faithlessness (his infidelity to his wife when he has relations in America with Martha Carter), Bobby Leacock, who has an actress wife who seems to be interested in nothing but the stage, knows the security of marital happiness and understanding. When he finally collapses at the Zoo, in this dramatic scene his wife goes off in an ambulance with him and they reveal their firm commitment to each other. Doctor Leacock and his wife are ludicrous figures in many ways, who certainly suffer terrible tragedy in the death of their daughter and the downfall of all his schemes. But their passion for each other gives them dignity. She is always faithful to "Daddy" as she speaks of him, and they go off together to the Lake District. Dr. Englander, the Fascist one, with the rather made-up, absurd continental wife, has a happy private life. His wife is there at the trial when he is finally sent to prison, and they are deeply united. And the head and top of all this, speaking against the chaos that happens in the world, speaking against the terrible pressures of organizational warfare and the horrible misuse of power, 
is this endurance of human love. In the marriage between Simon and Martha I do intend this lasting love to be there. I think Martha is not a wholly satisfactory wife to Simon. She leaves him at times that are very important to him; at times of great danger she is away from the country, but he would have wished it so. She is unfaithful to him with Bobby, but then she tells him that she can't help mothering people; and he is, at an important moment to her, impotent, unable at least, because of external pressures, to satisfy her at the time. But these discords don't really affect their relationship. Even at the end of the book when the children voice their mother, saying "If you get to be a nuisance, Mummy will send you away," I think this is only her mothering him and giving him a kind of rebuke. It is my intention to mirror in their marriage the absolute refuge there is for people in personal relationships, to allow them to escape from the terrible stress of public events. She is not a wholly successful wife, and that fact makes his whole life more difficult. This is all true enough, and one could easily detect such minor discords as this in all the other marriages. Usually, the wives are at fault, strangely enough. Wives in most of my other books are the better people, but in this case the wives are not so (I mean that Jane, for instance, in her fixation upon the stage, leaves her husband alone too much to cope with life). All the same, I do intend the marriage of Simon and Martha to be a good one. I had wanted to offset her faithlessness by his being unfaithful in her absence, a portion of the book which later I cut out because I thought the book too complex as it was. I think that these matters of unfaithfulness, when people are separate from each other, are totally unimportant compared with the real firmness of the affection between them. This is a book about enduring personal relationships and chaotic public ones.

F.M.: One of the most haunting passages in your fiction to my mind is the Prologue in Late Call, "The Hot Summer of 1911." I have not been able quite to define why this chapter looms so powerfully in one's retrospective vision as he goes forward with the novel. Would you wish to comment?

A.W.: It is very vital to the novel, in my planning of it. I wrote the Prologue particularly in the style of that period. One or two critics commented on this, and said, "Why is it written in this curious, rather lush Edwardian prose?" I meant it to be lush because it fits the garden of Eden and the age of innocence I am describing for Sylvia in her earliest years. Then Sylvia is cast out from the garden, it would seem forever, is violently beaten, and told in effect by her unsympathetic mother and boorish father, "You are nothing." This section is very vital because she is trying to lead a little girl (the other little girl, the daughter of a rather sophisticated and pretentious, empty, middle-class woman who is staying on the farm) to discover all the excitements of nature, the beauty of the world as she knows it. The little girl, of course, is the cause of Sylvia's punishment and loss of heartfelt innocence. Toward the end of the book, Sylvia rambles about the countryside trying to find her natural roots again, after coming to Carshall, the New Town, and finding no place for herself. She wanders off into the country at this time, utterly melancholic and self-absorbed, not being able to find those country roots 
from which she came. It's through helping and saving another little girl at the time when the lightning strikes the tree that she is brought back to some kind of spiritual poise, or one might say that secular grace is accorded to her. She finds a stability; and she is able to go on, and-within reason at any rate-help those who are dear to her. She finds some purpose in her own life, missing from it since those early years. In some sense even, she regains the Eden she had lost in 1911. So the Prologue is very, very important because it does lead full circle round. You are not told in the Prologue who the little girl is; and, I hope, it only becomes realized as the book goes on who she really is. Indeed, I was speaking the other day to a professor in one of the American universities who pleased me very much by saying that he had thought-but everyone told him he was wrong-that this little girl in the Prologue was the same person as Sylvia Calvert; and I was able to assure him that she was.

F.M.: In some moments I have thought that the New Town of Carshall in Late Call has something in common with the antiseptic but soulless societies projected in Brave New World and 1984. Harold in the novel seems to represent most centrally the values of this society, but I think he is also one of your most interesting characters. In him we have a man of good intentions who is not able to rise to the level of these intentions because of social prejudices of the most arid sort. I also feel that there is skilled counterpoint in your thematic development when you have Harold hardening against his homosexual son, Ray, soon after Harold's mother, Sylvia, has acquired, and tried to act in accordance with, the secular grace that has been hers since her moment of awakening under the tree. Would you wish to comment?

A.W.: Yes, Carshall is, I think, not really (at least, I didn't intend it to be) another brave new world society. It is a serious experiment to create some kind of united community. It's more mundane, more solidly based: it is based on actual "New Towns" that were built immediately after the war to provide for people from London. It's another kind of more firmly founded Blithedale. I don't think that such enterprises are wholly bad, far from it. Indeed, Sylvia, who finds it a very strange place to come to terms with and who in her intuitive percipience exposes its shams and its pretenses and its hollowness in many ways, is led to become quite a proud citizen of it, especially in the last part of the book when she goes to the hearing at which her son loses control (the public hearing about whether a meadow shall be built upon or not). She's very proud of the buildings in Carshall and she's right to be so, I think. Much that the people there are trying to do is excellent. Sally Bulmer, the social worker, is a representation of the partly positive side of life there. She does do good, but she puts her foot in it all the time. It's a place that has tried to make a blueprint of goodness, and you can't do that. She's a do-gooder for better or for worse, but I don't agree with people these days who are always blaming do-gooders. I think of J. B. Priestley who rightly said to me, "But how much worse to have a lot of dobadders." The thing about Carshall is that it's a do-good town, and it fails obviously to do good on the big scale that it had intended. But still it's bet- 
ter that it's trying to do good than to do bad. I don't have that kind of Huxley view about the brave new world; I think that, barring great catastrophe, the brave new world in Huxley's extreme version is unlikely to be achieved, but I do think that a brave new world is a good deal better than a cowardly old one. Harold in that town is a tragic figure because he, more than any of the others, has been the leading public man there; and like many such progressives, like the Padleys in The Mulberry Bush, he cannot believe that progress will ever be other than the way he once saw it going or believed it to be going. And progress in his opinion has been achieved. Particularly, progress has been achieved because he was led by his wife, Beth, a very strong person who has now died. She laid down what progress is, she was satisfied with the current kinds of change in society, and Harold worships her memory. Concepts of progress must not alter, just as the house must not alter, the children must not alter, nothing must alter. He'll fit his mother and his father in if he can. But how they're to be fitted into this contemporary world, which has already been decreed by Beth, which has been laid down by her, and which is therefore sacred, is hard to tell. Being a headmaster does not help, because being headmaster of a school means that he can always expect to be obeyed; and he is obeyed. He's a very patronizing man in his goodness. It's not insignificant that he's very good with the backward boys; but his book about them is called The Blokes at the Back of the Form, and it's patronizing in its approach. His attitude to his children is similar. He can't bear that his daughter is now acquiring social aspirations, and he doesn't want one of his sons to become a C. N. D., an anti-nuclear person. These are not the ambitions or causes that he fought for, and so they're out. When it comes to his homosexual son, Ray, he, as a progressive man, approaches the situation very well. He says, "Yes, he must go to a psychiatrist," but when Ray writes back and says that he does not want to go to a psychiatrist and acts at variance with Harold's progressive notions, Harold says, "Then I've finished with him." His set ideas and standards form the chief difference between him and Sylvia. She has no such categoric notions; she approaches life intuitively and says in essence, "Ray's always been good to me; he's a good boy; we can't finish with him; he's my grandson." Their approaches are quite different: Sylvia is intuitive (she has some kind of secular grace), whereas Harold is hardened, I am afraid, a man without grace, but with every sort of good works. The novel does reflect, I hope, not wholly against good works, because, as I have said, I don't think that bad works are a substitute for good works. Still, I don't think that good works are enough. And this is why we're given this oldfashioned sermon by the old Scotch preacher who tells us that good works alone are not going to suffice. His sermon comes home to Sylvia, because she's seen in this town good works without an inner grace to accompany them. So you could say that the town is good but somewhat soulless.

F.M.: In a lecture which I heard you give several years ago, you were critical of Virginia Woolf as being an experimentalist in vacuo and of Bloomsbury as being out of touch with the most pressing kinds of our contemporary reality, 
that is, the social reality we knew in the depression and in the Second World War and after. She represented a withdrawn kind of sensibility which had little to impart to the modern novelist and to the modern reader of novels. I would assume that you have modified this view to some degree. Would you care to comment?

A.W.: I have modified it to such a great degree that I am utterly ashamed to think that I ever said such a thing. I was fighting at this time, I suppose, on behalf of a re-look a the Victorian novel, not the neo-traditional approach which is so common now, at any rate in England, where people think that we should write novels like Trollope. But I felt that Dickens, in particular, and some other Victorian novelists, Meredith and so on, had been underestimated, that they had rather more to say to us now than people like Virginia Woolf in their anti-Victorianism had realized. I had read Virginia Woolf enormously as an adolescent, and therefore the first talk I ever gave on radio was an attack on her; and I said then, you know, that one must bite the hand that feeds one. She has continually fed me and my work, sometimes when I may not have been aware that this was so. In the 1940's and 1950's, I saw certain kinds of social patronage in her which I think are rather unimportant now, but which I thought more important then. Indeed, I don't think that she is so socially patronizing. I would say that the picture of Septimus Warren Smith, the shell-shocked clerk in Mrs. Dalloway, is altogether more percipient and sensitive and understanding than that of Leonard Bast by E. M. Forster in Howards End. And I admire her novels more than I can say now, in particular Mrs. Dalloway, The Waves, and Between the Acts. But I suppose I admire most of all The Waves which, I think, is really a very great novel indeed. I don't want to go too far in the other direction; I think that there are limitations within her works and they reflect her restricted experience. She was, for all sorts of reasons, a bluestocking; and coterie living cut her off from a great deal of life. She was very well aware of this, however. But how unimportant all this is, I think, can be seen from her worry that she couldn't do what Katherine Mansfield did. She felt that, because Katherine Mansfield had had an abortion and illegal operations and so on, somehow Katherine was one up on her. And this is so ludicrous when you think how much greater Virginia Woolf's novels are than Katherine Mansfield's stories. I have now the greatest admiration for Virginia Woolf's work; and I had to fight very hard not to allow the scheme and so on of The Waves to obtrude too much in No Laughing Matter, where I was in fact dealing with six principal characters much in the same way she did in The Waves.

F.M.: You have described in a recent talk as well as in The Wild Garden the importance of your family to your writing, with its combination of respectability and disreputable behavior, of gentility and Bohemia, particularly as these qualities were illustrated respectively in your mother and father. You feel that the different cultures represented in your father and mother and their conflict in your family heritage have been fruitful for your fiction. To what extent would you say that your parents are present in Billy Pop and 
the Countess, the Matthews father and mother, in No Laughing Matter?

A.W.: Well, very little as actual characters. My father had no literary interests whatsoever and no pretensions to being a writer. My mother, though in some ways a rather snobbish woman, was of impeccable moral character and had a very kind disposition. So it would be grossly unfair to my parents to think of them as prototypes of Billy Pop and the Countess. I should be horrified, indeed, to think they were in any way a representation of my parents. However, this book in its germination owed something to my early life. I had five brothers and they were all a good deal older than I was; and I used to hear a lot of stories about their early childhood before the First World War. I think in some degree the early part of No Laughing Matter, the scenes laid before the First World War and even the scene in 1919 when I after all was only six, do represent what I imagine the ethos of my family may have been in those days. I was able to recreate the past, if I did so successfully, partly from what I had heard the people in my family tell of those times. Certainly the mixture of social pretension and poverty, typical of people in my family, is also typical of the elder Matthews in my novel. My parents were not cruel as Billy Pop and the Countess sometimes are; but like them, my parents were not very successful as parents and rather negligent, I think. They also probably had servants of Regan's kind in No Laughing Matter, rather exploited servants because they themselves were rather poor, poorer than their social pretensions should have allowed them to be. But the differences between the six Matthews children and my own brothers is very great. My brothers, though having many excellent qualities, were not prosperous in various fields as the Matthews children are. This difference is the overriding one, so that from 1919 onwards, the last part of the book where they develop and become representatives of various facets of British life, they are indeed successes and a number of them are public figures. Some French commentators (this book was very popular in France) did think that this progress was rather schematic: that each of the children should have been so eminent in his own sphere in a worldly sense, at any rate, was a bit too much for these critics. But anyhow, this was very, very different from the situation in my own family. The plan of the book, as I conceived it, would allow me to represent the England after 1919 in various spheres and allow me to explore the degree to which human beings can make both a worldly success and a more inner success of their lives despite the appalling, cramping, and cruel atmosphere of their childhood. I also wanted to show the degree to which the weapons they used (in this case, particularly, clowning and farce and laughter, hence No Laughing Matter) became both necessary defenses for them against the cruelty of their parents, and limiting forces and ironies when later as men and women they wished to develop.

F.M.: You have indicated that you will no longer do work in the short story and the drama, since the writing of novels now engages you so completely. Yet you have written a play of distinction, The Mulberry Bush, and some plays for radio and television. And, of course, you are interested in, and use, the conventions of drama, to the extent of writing several short plays as "inter- 
lude" passages in No Laughing Matter. What would you say is the function of these plays in this novel, particularly since these plays seem to be parodies of modern dramatists that most people know? Would you say something, incidentally, about your use of parody in the novel and perhaps indicate the dramatists whom you were imitating in the various insets in the book?

A.W.: Yes, I used the conventions of drama, partly as a way of lightening what is a very long novel but much more importantly because the family is a self-dramatizing one. It seemed appropriate, therefore, that just as they have this device of The Game, which is very important to the book (The Game in which each of the children plays an adult member of the family and which becomes a sort of burlesque enterprise with music-hall songs and popular songs of the time), so vital scenes where the family all come togetherdecisive moments in the family-I cast in dramatic form to underline this dramatic side of their natures. I mention The Constant Nymph once or twice in the book and The Forsyte Saga; the whole book is a kind of antiConstant Nymph and anti-Forsyte Saga. It's an anti-Forsyte Saga insofar as it suggests that the family is not always a unit which is helpful to the individual; and it's an anti-Constant Nymph insofar as it makes fun of the idea that a Bohemian life is in itself a happy one for those who are brought up in it. We go back now to the idea of Hard Times, that circus clowns lead necessarily a good life. It seems to me that the Bohemian life can be a terribly destructive one to people. However, since the Matthews family is theatrical by nature, I cast the main family scenes in a series of parodies of contemporary plays; and I made them parodies of the successful dramatists of the time in which the book is laid, from 1911 to modern times, till the 1960's anyway. They are the sort of dramatists that would have influenced not only the children but the parents. The mother is a sort of matinee-going, smart London woman, and the father has pretensions to being a literary man. So they are influenced by the theatre of the period, and from it they get the romantic and social idées reçues of their time. We get a Maugham parody, "Before the Week-End"; we get a Shavian parody, "Parents at Play: A Lesson in Lamarckian Survival"; and we get a Chekhov parody, "The Russian Vine: An English Play." This last is an imitation of a special kind of Chekhov play: here I am not so much getting at Chekhov as at the kind of use to which Chekhov was put in the 1930's when he was very popular on the English stage. The English created a special, genteel version of Chekhov, wistful and touching for the people in the middle class who felt themselves on the way out and who suggested that Chekhov was really an English author who had written about them. Then there is "French Windows: An Interrupted Play," in which the parents appear as in Rattigan's Separate Tables at a hotel rather at their best and in a plucky light; and finally, there is "Pop and Motor: A Catastrophe," a parody of Beckett's Endgame in which the parents are exploded-literally exploded by a bomb, and in which we see Billy Pop and the Countess brought down to their very bedrock hopes and illusions. It is, of course, an anachronism, for Beckett came after this period. But in the Shaw parody we are given a Shavian joke of 
exactly such a kind where Shaw's Intelligent Woman's Guide to Socialism and Capitalism is mentioned before it was published. So the introduction of the Beckett parody anachronistically is a kind of double joke: my joke about the Shavian joke. Such alienating devices seemed to me peculiarly necessary in a bourgeois family saga novel where the reader is by custom likely to immerse himself and lose sense of the full meaning of the book. So ends the cycle of the middle-class plays in this novel. I spoke earlier of the effect of Borges and Nabokov on me in this way. This novel is full not only of parody but of other alienating devices. One of them, for example, is the constant use of the language, interspersed into the narrative, of Macbeth, to depict the evil behavior of the parents, the evil murder of the kittens. Another is the use of the cinematic device for the opening passages; and another, indeed, is the attempt to show the characters in a kind of "covered wagon" situation in which they express their dreams and aspirations in a moment of common celebration and describe the Eldorado which they should like to have seen themselves in but which they are never to be in. Yet another is the introduction of Rupert's difficulties in understanding Malvolio whom he is to play on the London stage. Malvolio is here introduced in the very section where the Matthews (and by implication the British middle class) are having to learn that compassion must be given to the German Jewish refugees from Hitler although they are often rebarbative; Malvolio, the fanatic Puritan who is not completely a fool and who is ultimately deserving of our compassion, Rupert can only dimly comprehend at first. Malvolio is, then, an exact parallel to the refugees whom the British middle class find repellent despite the genuineness of their claims upon British sympathy and generosity. When Rupert finally plays Malvolio with "love," he connects the pompous factotum with the suffering man beneath. Just so, he sees that his initial reactions to Mr. Birnbaum, the German writer of children's stories, have been to surface annoyances, not to the suffering man beneath. Just so, the Matthews children (and all the English middle class) must overcome their revulsion and compel themselves to value the strange and unfamiliar in the Jewish refugees. The novel is very thematically divided. It begins, I think, with these "Eldorado" aspirations, after the wild West show; it moves on to the blasting of these young people's hopes with the murder of the kittens; it proceeds to the 1920's, a period largely of egoistic development on the part of the characters in which they renounce many opportunities that they would perhaps have liked to have had later. Incidentally, Quentin, the loner, the one who has been brought up by his grandmother, is the first during that period of the early 1930's to make a public perception when he goes to Russia and has the courage to speak out against the regime. Then the novel moves on to the 1930's when we see the Matthews children moving into the public sphere; we also see them as they confront the first big invasion that England had faced, I suppose, since the Norman Conquest: the arrival of the German-Jewish refugees. And like other invaders these people were not always at their most attractive, as indeed people turned out of their homes are not likely to be. One of the truths the English liberals-and, in general, 
my characters (although Sukey is rather a conservative figure) are liberal in intention-had to learn was this: if they are going to receive the refugees, they have to receive them with warts and all. And they do not learn this lesson very easily. They can't hand it out any longer; they get it handed out to them by the refugees from Germany. The only one who really behaves badly by the refugees is, ironically, Gladys, who is perhaps the best-hearted and the kindest of all of the children but who cheats a refugee in a deal over a painting. But she does so because she's so deeply in love with a man who is a trickster, and she is, besides, a kind of tragic clown figure. She always does a pratfall, whatever she does, poor dear; and she's also the fat, rather moving figure of the book, and perhaps does not see the full consequences of her impulsive acts. And then comes the war, which again tests them. After the war, we see them having to go out and face a new world, to learn not to dominate the refugees coming in but to accept the authority of those who are coming up from below in the social structure. So Rupert has to learn that the new proletarian drama isn't suited to his particular kind of acting, Sukey has to learn that the old country gentry stories which she used to read on the radio are not wanted any more, and Marcus and Margaret have to come to terms with a new Arab nationalism. Quentin perhaps makes the least satisfactory adjustment. He lets himself down pretty completely: for the sake of his clowning act or his popular act on the television, he's quite prepared to exacerbate the hostility to the Chinese in Singapore. The Matthews are now dealing with the outside world as England has had to do and as the middle class have had to do, not from a position of strength but from a position of weakness. So the book is thematic, and it uses a lot of parodies and other such conscious devices in the course of this thematic development.

F.M.: In No Laughing Matter I think we see the culmination of one chief theme in your work, the adverse effects of the manipulation of an individual by those who are stronger and more unscrupulous. The novel also seems to me, in large part, to be a tragic book, because it presents so graphically the wasted existences of the Matthews children, all of whom have much talent. With respect to these children, you once said that Marcus, Margaret, and Quentin are children of their mother, who are almost destroyed by the need for light which nearly turns to realism (or cynicism I would judge); whereas Rupert, Gladys, and Susan are the children of their father who are almost destroyed by the need for sweetness which nearly turns to "self-consoling delusions." Would you want to comment on these statements? I might say that I feel that Marcus, Margaret, and Quentin are the most interesting of the six children to me and seem to me to be the most deeply conceived. I wonder also if you would comment on the compensatory role of fantasy in the Matthews children, which they turn to when their parents fail to understand them, and indeed at many times of crisis in their lives. It brings out their talents, certainly, but might it not also be thought to undermine them, encouraging them to escape reality?

A.W.: I think that No Laughing Matter is a different book from all the others I 
have written, in this respect. All the other novels are about self-discovery, and at the end of the book the characters have learned through crisis and suffering what their real nature is. We leave them with a question mark; they go on to a new life but we don't know how they will conduct themselves. No Laughing Matter, on the contrary, shows the development of people, six people, throughout their lives; and we end with knowing what they did actually perform. Some readers may see their final situation as tragic, because what they do perform is clearly less than what the characters in my other books may perform. That is to say, actuality is less than potentiality. But I don't see this result as so tragic because it seems to me that, given all the terrible disadvantages of the childhood that they have suffered, the Matthews children, in their various ways, do achieve a very great deal. Not only in the worldly sense, though they do achieve in this sense, too: one becomes a very good novelist, another one a successful actor, another one a picture dealer and owner of a cooperative factory, another one an important and courageous journalist, another one a good wife and mother, and the last one a kind and good, although an unhappy, woman. But their achievement goes further still: they do, I think, reveal a great internal development, a development that is all the more important because they have suffered so much from the imposition of cruelty and arbitrary power. The exercise of power by their parents is malicious, cruel, and direct. As a result of suffering, they develop a certain kind of irony. Many readers are shocked, after the death of their parents, to find the Matthews progeny, now grown men and women, still playing The Game which they had learned to play as children in order to deal with their parents. These readers may be justified: I think it is a limitation of human beings that they retain much of their childhood for the rest of their lives and never get completely free of it. To this extent, the book is deterministic. But what the Matthews children have achieved within the meanwhile is considerable. What they achieve in the material sense counts in their favor, but the change of character which each one shows is more important still. At the end of the book, for example, Margaret Matthews and Marcus Matthews have a row out in Morocco, where they are. Margaret says to Marcus, "Your malice is detestable. All through your life it's been the same. Restless, impetuous, never stopping for thought, destroying wherever you go like a greedy hen." Marcus, in his turn, cries, "And you just sit on life with your bony bottom until you've pulverized it into sand." Margaret then walks through the market where all life is teeming and muses upon Marcus's words to this effect, "Surely, he can see that I have not lived my whole life dried up and cut off from things. I have absolutely involved myself in life as much as I can." And one sees that her thought is true. Her novels are a little Jane Austenish, they are a little dry; but still she has amazingly confronted life. And Marcus, who has been accused of being bitter, buries himself in the sand and thinks to himself to this effect, "She little knows how I've curbed my malice, how I've curbed my cruelty." One sees that he can still be malicious as he has just been to her; but, nevertheless, one also sees that he has founded his cooperative factory with trust, with 
a kind of innocence which he knows to be almost absurd. But he has done something which needed courage, a lot of hard work, and has largely effaced the malicious part of himself in doing it. And the same argument can be made for all the other characters, except perhaps for Quentin, who made his achievement early and who ends somewhat tragically as a rather destroyed person. And there is the younger generation coming up to take on from their elders. So I don't see the novel as a tragic one. I see it as a less open-ended one, one which circumscribes the characters in a way that my earlier novels do not, because in them we are left with a possibility of anything happening for those redeemed people. In No Laughing Matter the people are not redeemed or they are only partly so. They are of clay. As Margaret looks out over the Atlantic from the shores of Morocco and thinks that there may still be an Eldorado, we know that the lives of the Matthews children have proved that Eldorado is still a long way off. But they do triumph over the obstacles which their parents have put in their way, and over the purely impersonal circumstances which move in on them from society itself. I may have been trying to say that the triumph of the Matthews men and women is the muted and partial one that is the only possible one for most of us to achieve. The Matthews men and women, I think, achieve a lot more than many people in their same circumstances would. My novel, as I have said, is tragic only in the sense that realization never comes up to expectation. What they have tried to do and what they do succeed in doing, I may say, is to escape the worst of the adverse effects of their being manipulated by others, especially their parents. They have been able to survive because they have become tough on the outside, have, as I said before, been made relatively invulnerable by irony. In making the note about the six children being almost destroyed (Marcus, Margaret, and Quentin by the need for light; Rupert, Gladys, and Susan by the need for sweetness), I would have to stress the word "almost." I can't deny that I have put most of myself into Marcus, Margaret, and Quentin, although I would not want to say that in doing so I am ready to prefer light at all times to sweetness. I would grant that light does more in the world than sweetness, is a more active force if you will, and perhaps I do finally elevate it over sweetness. In their games and indeed throughout their lives, the Matthews children do, as you say, resort to fantasy: maybe they even overdo it. But remember that at least four of them are artists or creative persons: Rupert in the theatre, Quentin in journalism, Margaret in the novel, and Marcus in painting and drawing. It would only be natural for them to use their imaginations. So fantasy as well as irony becomes a protective device for them. They are too sensitive, of course, to escape damage at the hands of their careless and sometimes malevolent parents; but their sensitivity gives them some of the imaginative resources which allow them to objectify their situation as well as to suffer in it. So fantasy as well as irony and laughter (and the three are, after all, hardly to be separated) helps them to survive to an adulthood that is in each individual honorable and admirable. I must say again that fantasy is not so much an escape from reality for them as a way of enabling 
them to see reality for what it is. It lends perspective, you know, to the elements of their experience which otherwise they might not be able to sort out, and understand. I can't see that in any sense their exercise of fantasy undermines them as responsible persons, and I wouldn't want to go along with that part of your statement.

F.M.: I assume that a writer tends to regard his latest book as his most important one. But I think I have detected some other reasons for your high valuation of No Laughing Matter. Would you want to say a few words, in general, as to what the book has meant for you and your development, possibly also something about what you may consider its intrinsic worth to be.

A.W.: A writer is just as fond of his last book as a parent is of his last child. I hope that I may be excused for this human sort of indulgence for something that I have created. But I do think, really, there are some quite objective grounds for my satisfaction with it. In it I have attempted to do more than I have in any other of my books. The canvas is less broad as to the number of characters than in Anglo-Saxon Attitudes, but the canvas is broader, I think, as far as what I do is concerned. You might say I have six Gerald Middletons in this book, toward whom I feel the same kind of proprietary fondness as I do for the recognizable single protagonist in most of my other books. I have, I hope, been able to exteriorize more successfully in this book than in my others my sense of the moral forces, conflicts, perplexities that haunt our lives. In my other novels, I have made these matters personal, rather all too personal I would judge. In No Laughing Matter, my sense of good and evil is not only objectified in the conflicts present in my characters, but good and evil are the forces determining the family world, and the outward social and political world in which the Matthews children have to live. I hope it is not immodest for me to say, too, that I may have gone deeper into some of my characters in No Laughing Matter than I ever have gone before; at least, I would like to think I have done so in Margaret, in Quentin, in Marcus, maybe even in Rupert. I may have done something like Virginia Woolf tried to do in The Years-I fear unsuccessfully for it is her least good novel-showing how members of a family survive, with triumph and with agony, through a long period of social change, how the fiber of each one of them is tested again and yet again as he lives out his life in time. And perhaps I can say that as in Virginia Woolfs world, in the world of No Laughing Matter it is not time that is the victor but something hard and imperishable, something that refuses to be daunted, in human nature itself. 